\title{
Notes on the Vertebrates of northern Pará, Brazil: a forgotten part of the Guianan Region, III. A new species of Microcaecilia (Amphibia: Gymnophiona: Caeciliidae) Notas sobre os vertebrados do norte do Pará, Brasil: uma parte esquecida da Região das Guianas, III. Uma nova espécie de Microcaecilia (Amphibia: Gymnophiona: Caeciliidae)
}

\author{
Adriano Oliveira Maciel', Marinus Steven Hoogmoed' \\ 'Museu Paraense Emílio Goeldi. Coordenação de Zoologia
}

\begin{abstract}
A new species of Microcaecilia is described from the municipality of Óbidos, state of Pará, in the Brazilian part of the Guianan Region. The new species has a high number of secondary annuli, monocuspid vomeropalatine teeth, and other characteristics that together differentiate it from the other eight known species of the genus.
\end{abstract}

Keywords: Brazil. Guianan Region. Gymnophiona. Microcaecilia. New species.

Resumo: Uma nova espécie de Microcaecilia é descrita do município de Óbidos, estado do Pará, na porção brasileira da região das Guianas. A nova espécie tem um número alto de anéis secundários, dentes vomero-palatinos monocúspides e outras características que, em conjunto, a diferencia das outras oito espécies conhecidas para o gênero.

Palavras-chave: Brasil. Região das Guianas. Gymnophiona. Microcaecilia. Nova espécie.

Como citar este artigo: MACIEL, A. O. \& M. S. HOOGMOED, 2011. Notes on the Vertebrates of northern Pará, Brazil: a forgotten part of the Guianan Region, III. A new species of Microcaecilia (Amphibia: Gymnophiona: Caeciliidae). Boletim do Museu Paraense Emílio Goeldi. Ciências Naturais 6(1): 67-72.

Autor para correspondência: Adriano Oliveira Maciel. Museu Paraense Emílio Goeldi. Coordenação de Zoologia. Av. Perimetral, 1901 - Terra Fime. Belém, PA, Brasil. CEP 66077-830 (aombiologo@yahoo.com.br).

Recebido em 17/02/2011

Aprovado em 18/03/2011

Responsabilidade editorial: Hilton Tulio Costi

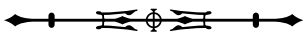




\section{INTRODUCTION}

The genus Microcaecilia Taylor, 1968 contains eight recognized species, most from Amazonia, north of the Amazon river, except for M. taylori Nussbaum \& Hoogmoed, 1979, which is distributed from the Guianan Region to south of the Amazon river in the state of Pará, Brazil (Maciel \& Hoogmoed, in press), and $M$. supernumeraria Taylor, 1969, which has São Paulo as type locality (considered "imprecise" by Frost, 2011), with no additional records since its description based on one specimen (Taylor, 1969).

Recently three new species were described from the Guianan Region, M. grandis Wilkinson, Nussbaum \& Hoogmoed, 2009 from Suriname, M. iyob Wilkinson \& Kok, 2010 from Guyana, and a third species by Maciel \& Hoogmoed (in press) from northeastern Pará, Brazil, all based on few type specimens (one, one, and four, respectively). Here we describe a new species from the Brazilian part of the Guianan Region based on one specimen recently collected during one of the expeditions of the Calha Norte Project (Avila-Pires et al., 2010) to northern Pará, Brazil. Probably other new species of Microcaecilia, will be recognized as indicated in the recent literature (Wilkinson et al., 2009; Maciel \& Hoogmoed, in press).

\section{TAXONOMY}

\section{Species description}

\section{Microcaecilia trombetas sp. nov.}

Microcaecilia unicolor: Avila-Pires et al. 2010: 68, 109. Holotype: MPEG 26476 (Field number CN502), mature male, Floresta Estadual (FLOTA) Trombetas (S $0^{\circ} 57^{\prime}$ 45.97" W55 31' 20.28"), municipality of Óbidos, state of Pará, Brazil, 21-IV-2008, collected by M. S. Hoogmoed and W. Rocha .

Diagnosis: Primary annuli 116. Secondary grooves 91. Eye not visible. Premaxillary-maxillary teeth extending beyond the level of the posterior margin of the choanae.
Vomeropalatine teeth monocuspid. Small terminal shield, one half (only on left side) annular groove beyond posterior level of the vent. Dermal scales starting at 8th annular groove; no indication for the presence of subdermal scales.

Microcaecilia trombetas sp. nov. differs from most other Microcaecilia (except M. supernumeraria with 93 secondary grooves instead of 91 in $M$. trombetas sp. nov.) in having a higher number of secondary grooves and from M. rabei (Roze \& Solano, 1963), M. taylori Nussbaum \& Hoogmoed, 1979, M. grandis Wilkinson, Nussbaum \& Hoogmoed, 2009, M. iyob Wilkinson \& Kok, 2010, and Microcaecilia sp. nov. Maciel \& Hoogmoed (in press), in having monocuspid instead of bicuspid vomeropalatine teeth; from M. iyob it also differs in having more primary annuli, 116 instead of 97 . It differs from $M$. supernumeraria in having distinctly less primary folds (116 instead of 143), in the scales starting at the 8th annular groove (instead of at the first primary groove), in having higher numbers of vomeropalatine and dentary teeth and in having a less slender body (length/width 34.1 instead of 41.6 times).

Description of the holotype: An adult male (Figure 1) with a total length of $218 \mathrm{~mm}$. Multiple testis lobes and abundant fat bodies. Phallodeum partially extruded (Figure 2), consisting of a short $(2.5 \mathrm{~mm}$ ) cylinder (diameter $1.6 \mathrm{~mm}$ ) which at the top shows a vertically divided inverted part that could not be everted further. A longitudinal ventral incision of approximately $25 \mathrm{~mm}$ is present near mid body. Total length 34.1 times body width. Head slightly narrower than body; dorsum of head slightly convex in lateral view. Margin of the upper jaw curving down, with the highest point of the concavity formed at the level of the tentacle openings. Snout projects $1.2 \mathrm{~mm}$ beyond mouth. Tip of snout rounded in dorsal and lateral views. Mouth slightly opened, with premaxillary-maxillary and dentary teeth visible externally. Nostrils subcircular, visible from above. Eyes not visible. Tentacle openings circular and slightly elevated above the skin, laterally positioned, near margin of mouth, slightly closer to corner of mouth than to nostrils, visible from 

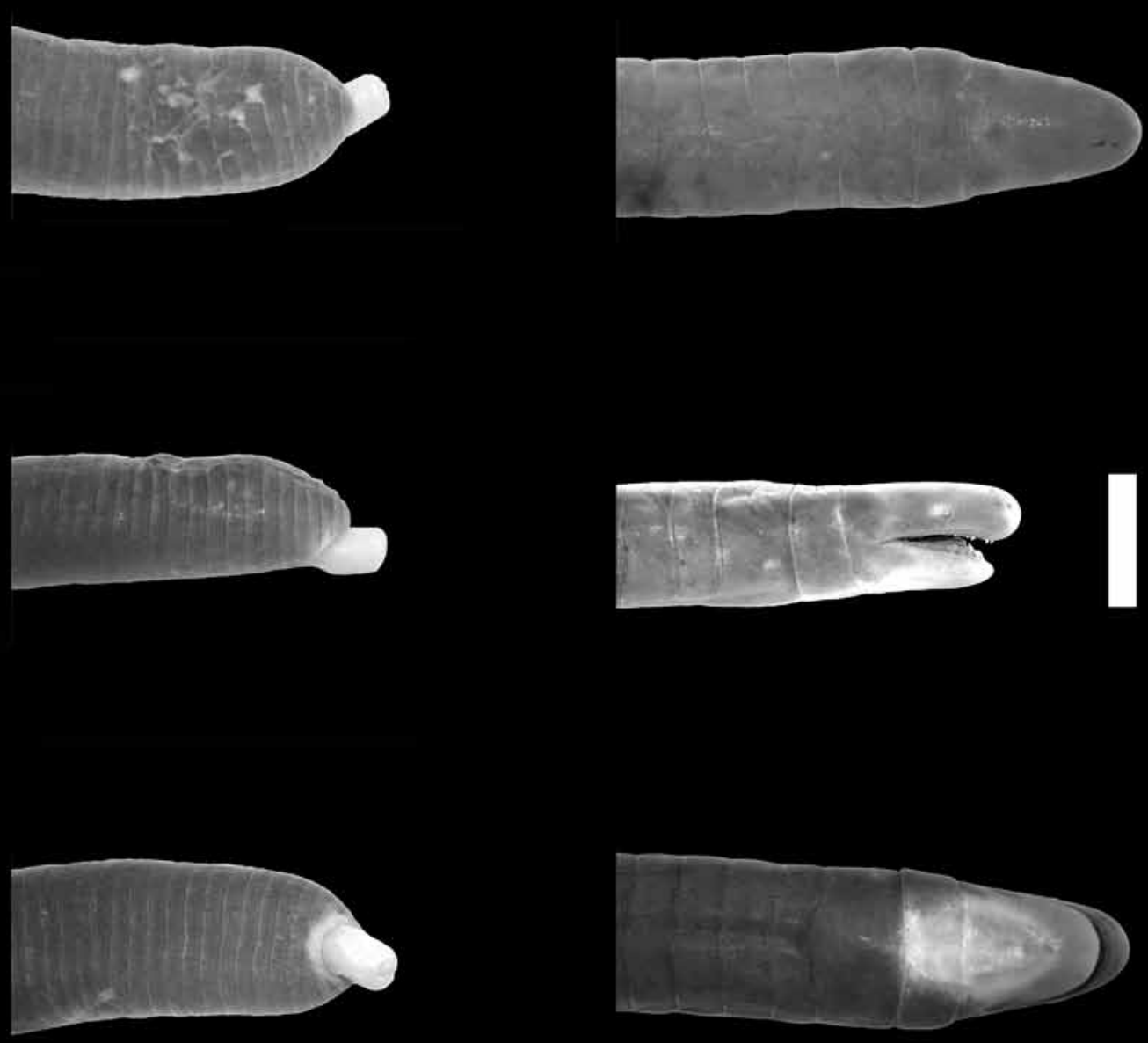

Figure 1. Holotype of Microcaecilia trombetas sp. nov. (MPEG 26476). Left column posterior part of body with partially extended phallodeum, dorsally (above), laterally (middle) and ventrally (below). Right column head and anterior part of body, dorsally (above), laterally (middle) and ventrally (below). White bar represents 5 mm. Photos: Ângelo C. M. Dourado.

above. Nuchal grooves distinct dorsally, laterally and ventrally, except the third which ventrally is incomplete. First collar narrower than second; distance between first and second nuchal groove $1.6 \mathrm{~mm}$, and distance between second and third nuchal groove $2.6 \mathrm{~mm}$. A dorsal transverse groove is present on each collar, smaller on the first one. A very thin longitudinal ventral groove (only visible under stereo zoom microscope) appears on the first nuchal collar running from the second nuchal groove to the throat. There is another very thin transverse groove on the ventral surface of the first nuchal collar, forming a cross with the other one. Body semi-cylindrical, slightly wider than deep. Width along the body may slightly vary, narrower at the terminal region. Primary annuli 116. Primary annular grooves completely encircling the body, except a few grooves that are ventrally incomplete (7, 8 , and 19 - 31), and two (plus one secondary groove) that are interrupted by the vent. Secondary grooves 91; 69 of them complete, starting between primary annular grooves 24 and 25. A small terminal shield; one half

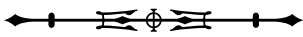




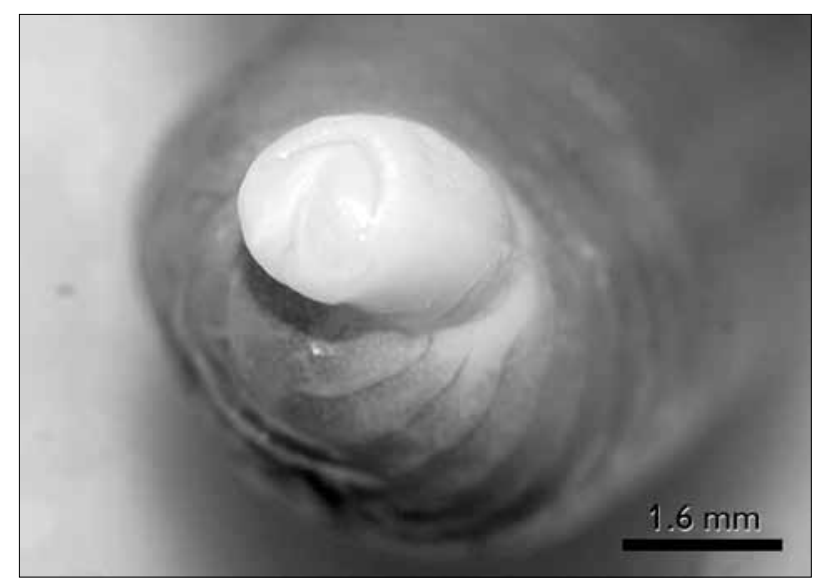

Figure 2. Holotype of Microcaecilia trombetas sp. nov. (MPEG 26476). Detail extended phallodeum. Photo: AOM.

(only on left side) secondary annular groove posterior to the level of the posterior margin of the vent. Vent with twelve denticulations: six on the anterior and six on the posterior margin. Dermal scales starting at 8th annular groove, with at most four rows per body annulus. Scales at 8 th primary groove small and narrow, $(0.2 \times 0.4 \mathrm{~mm})$; larger posteriorly (e.g. $0.7 \times 0.9 \mathrm{~mm}$ at 100 th primary annulus). Choanae circular, due to the preservation it was not possible to measure them. Tongue anteriorly attached to the mandibular mucosa, no narial plugs on tongue. Premaxillary-maxillary teeth 17 , with little variation in size, posterior maxillary teeth smaller. Premaxillary-maxillary series extending posteriorly to beyond the level of the posterior margin of the choanae. Vomeropalatine teeth 21, monocuspid, with no apparent variation in size; teeth smaller than in all other series. Dentary teeth 15, slightly larger than premaxillary-maxillary teeth; size of teeth decreasing posteriorly. More data in Table 1.

Colour: Holotype in life "Body purplish blue. Lower jaw pink with inner side bordered by white, throat [including ventral part of first nuchal collar] blueish. Area around vent pink" (fieldnotes MSH). In preservative the body is dark gray and the light areas mentioned above are cream. An $U$-shaped, cream area on the snout that connects the nostrils. Mandibles covered by a U-shaped cream area. The tongue, mandibular mucosa and palatal mucosa are grey, the palatal region darker than the rest.

Etymology: The name of the species refers to the type-locality, FLOTA Trombetas, and is a noun in apposition.

Distribution: The species is only known from the type locality on the southern part of the Guianan Region (Figure 3).

Natural history: The specimen was collected in 'terra-firme' (non-inundated) forest in a pitfall (no. 15 in trail 1) installed at an altitude of $350 \mathrm{~m}$. For a description of the general area of FLOTA Trombetas see Avila-Pires et al. (2010).

Table 1. Morphometric and meristic data (in $\mathrm{mm}$ ) for the holotype of Microcaecilia trombetas sp. nov. Between brackets total length in life.

\begin{tabular}{l|c}
\hline Total Length (in life) & $218(227)$ \\
\hline Weight in life & 6.4 grams \\
\hline Head width at jaw articulation & 5.2 \\
\hline Head length & 6.9 \\
\hline Head height at corner of the mouth & 3.9 \\
\hline Height at mid-body & 5.4 \\
\hline Width at mid-body & 6.4 \\
\hline Width at the first nuchal collar & 5.8 \\
\hline Width at five folds behind the vent & 5.6 \\
\hline Width at the vent level & 3.2 \\
\hline Intertentacular distance & 4 \\
\hline Distance tentacle to nostril & 2.3 \\
\hline Distance tentacle to corner of mouth & 2.6 \\
\hline Distance tentacle to margin of mouth & 0.7 \\
\hline Internarial distance & 1.3 \\
\hline Distance nostril to margin of mouth & 1.2 \\
\hline Snout projecting beyond mouth & 1.2 \\
\hline Primary annuli & 116 \\
\hline Secondary grooves & 91 \\
\hline Complete secondary grooves & 69 \\
\hline Pnnular grooves interrupted by vent & 17 \\
\hline Dotal lengthMidth at mid-body & 34.1 \\
\hline
\end{tabular}

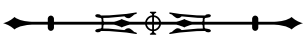




\section{DISCUSSION}

In the Guianan Region, Microcaecilia is the most diverse genus of Gymnophiona, and recently some new species have been described, either from specimens collected recently or from specimens that earlier had been relegated to other species. Taylor (1968) designated a lectotype for Microcaecilia unicolor from Cayenne, French Guiana and described a specimen from Guyana under that name. Taylor $(1969,1972)$ recognized that in his monograph of 1968 he referred the specimen of Guyana to M. unicolor with "some hesitancy" due to the lower number of annuli and higher number of premaxillary-maxillary teeth than in the other known specimens from French Guiana. Wilkinson et al. (2009) state that the specimen studied by Taylor (1968) from Guyana and the specimens from Suriname cited as M. unicolor by Nussbaum \& Hoogmoed (1979), are possibly undescribed species, or in the case of the Suriname specimens that they could represent juveniles of $M$. grandis. Recently, Wilkinson \& Kok (2010) described M. iyob, based on the same Guyanan specimen that earlier was used by Taylor (1968) for his description under M. unicolor.

Maciel \& Hoogmoed (in press) made a taxonomic study of the Gymnophiona of Brazilian Amazonia, and in

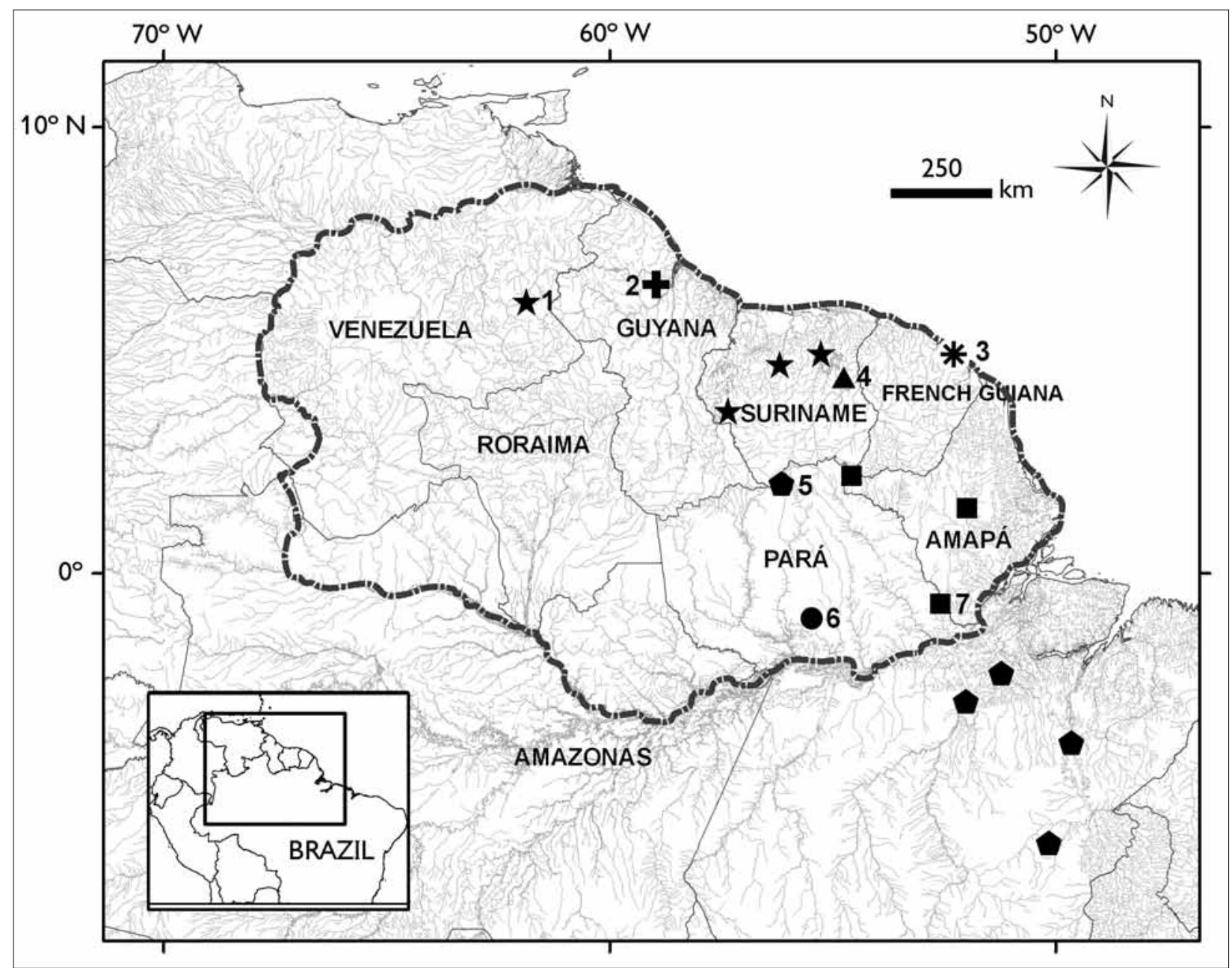

Figure 3. Map of the distribution of the genus Microcaecila in the Guianan Region (limits indicated by the line of dots and dashes) and adjacent part of Pará. Type localities indicated by numbers. M. rabei (stars, 1), M. iyob (cross, 2), M. unicolor (asterisk, 3), M. grandis (triangle, 4), M. taylori (pentagons, 5), M. trombetas (dot, 6), M. sp. nov. Maciel \& Hoogmoed (in press) (squares, 7).

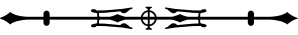


that paper cite some specimens of Microcaecilia from the Guianan Region that could represent undescribed forms.

Avila-Pires et al. (2010) erroneously considered the specimen here described to be $M$. unicolor and they cited its presence in FLOTA Trombetas under that name. Upon closer study of this specimen it turned out to belong to a species different from $M$. unicolor, which is here described.

\section{ACKNOWLEDGEMENTS}

Ângelo C. M. Dourado made the photos of the holotype. The first author was supported financially by the Conselho Nacional de Desenvolvimento Científico e Tecnológico (CNPq 132729/2007-5). Conservação Internacional (CI-Brasil) financed travel from Belém to Santarém and the costs of staying in the field. Mining company Rio Tinto covered the costs of transport from Santarém to FLOTA Trombetas and was responsible for logistics in the field. The field work was done under license 001/2008 of the Secretaria Estadual do Meio Ambiente (SEMA-PA).

\section{REFERENCES}

AVILA-PIRES, T. C. S., M. S. HOOGMOED \&W. A. ROCHA, 2010. Notes on the Vertebrates of northern Pará, Brazil: a forgotten part of the Guianan Region, I. Herpetofauna. Boletim do Museu Paraense Emílio Goeldi. Ciências Naturais 5(1): 13-112.
FROST, D. R., 2011. Amphibian species of the world: an online reference. American Museum of Natural History, New York. Version 5.5. Available at: <http://research.amnh.org/vz/herpetology/ amphibia/>. Accessed on: 15 February 2011.

MACIEL, A. O. \& M. S. HOOGMOED. Taxonomy and distribution of Gymnophiona of Brazilian Amazonia with a key to their identification. Zootaxa (in press).

NUSSBAUM, R. A. \& M. S. HOOGMOED, 1979. Surinam caecilians, with notes on Rhinatrema bivittatum and the description of a new species of Microcaecilia (Amphibia, Gymnophiona). Zoologische Mededelingen 54(14): 217-235.

TAYLOR, E. H., 1968. The Caecilians of the World. A taxonomic review: 1-848. University of Kansas Press, Lawrence.

TAYLOR, E. H., 1969. A new caecilian from Brasil. University of Kansas Science Bulletin 48: 307-313.

TAYLOR, E. H., 1972. Squamation in caecilians, with an atlas of scales. University of Kansas Science Bulletin 49: 989-1164.

WILKINSON, M., R. A. NUSSBAUM \& M. S. HOOGMOED, 2009. A new species of Microcaecilia (Amphibia: Gymnophiona: Caeciliidae) from Surinam. Herpetologica 65(4): 413-418.

WILKINSON, M. \& P.J. R. KOK, 2010. A new species of Microcaecilia (Amphibia: Gymnophiona: Caeciliidae) from Guyana. Zootaxa 2719: 35-40.

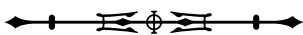

